\title{
ANALISIS PENDAPATAN USAHATANI JAMUR TIRAM PUTIH (Pleurotus ostreatus) DI DESA SINGAJAYA KECAMATAN CIBALONG KABUPATEN TASIKMAYA
}

\author{
ADAM NURHUSAENI*, MUHAMAD NURDIN YUSUF, BUDI SETIA \\ Mahasiswa Fakultas Pertanian Universitas Galuh. \\ *Email : adam.nurhusaeni93@gmail.com
}

\begin{abstract}
ABSTRAK
Produksi jamur tiram putih dipengaruhi oleh teknik budidaya untuk memperoleh produk yang berkualitas baik. Dalam kegiatan budidaya jamur tiram putih, pendapatan petani dapat dipengaruhi oleh besarnya skala usaha, ketersediaan modal, harga jual produk, ketersediaan tenaga kerja keluarga dan tingkat pengetahuan dan pengalaman petani. Tujuan penelitian ini adalah untuk mengetahui besarnya biaya, penerimaan dan pendapatan usahtani jamur tiram di Desa Singajaya Kecamatan Cibalong Kabupaten Tasikmalaya dan Kelayakan usahatani di Desa Singajaya Kecamatan Cibalong Kabupaten Tasikmalaya. Metode yang diterapkan pada penelitian ini yaitu metode deskriptif kuantitatif dengan pendekatan studi kasus. Sumber data pada penelitian ini yaitu data primer dan sekunder dengan teknik pengumpulan data melalui studi lapangan dan studi kepustakaan. Sampel yang diambil dalam penelitian ini adalah menggunakan purposive sampling Hasil penelitian menunjukan : 1). Besarnya biaya produksi yang dikeluarkan oleh petani jamur tiram yang berada di Desa Singajaya Kecamatan Cibalong Kabupaten Tasikmalaya adalah sebesar Rp 4.654.846,38 dan penerimaan yang diperoleh petani jamur tiram sebesar Rp 10.505.000 dalam satu kali proses produksi. Pendapatan yang diperoleh petani jamur tiram sebesar Rp 5.850.153,62 pada satu kali proses produksi. 2). Usahatani jamur tiram, apabila dilihat dari segi ekonomis diusahakan. dilihat dari nilai R/C 2,2 artinya setiap Rp 1,00 biaya yang dikeluarkan diperoleh penerimaan sebesar 2,2 dan memperoleh pendapatan 1,2 .
\end{abstract}

Kata Kunci : Pendapatan Usahatani Jamur Tiram

\begin{abstract}
The production of white oyster mushrooms is heavily influenced by cultivation techniques to obtain good quality products. In white oyster mushroom cultivation activities, farmers' income can be influenced by the large scale of the business, the availability of capital, the selling price of products, the availability of family labor, and the level of knowledge and experience of farmers. The purpose of this study is to find out the cost, receipt, and income of oyster mushroom farmers in the Singajaya Village Cibalong District Tasikmalaya Regency and The feasibility of farming in Singajaya Village Cibalong District Tasikmalaya Regency. The method used in this study is a quantitative descriptive method with a case study approach. The data sources in this study are primary and secondary data with data collection techniques through field studies and literature studies. The sample taken in this study is using purposive sampling The results of the study show: 1). The amount of production cost incurred by oyster mushroom farmers located in the Singajaya Village cibalong district Tasikmalaya Regency is $R p$ 4,654,846.38 and the acceptance obtained by oyster mushroom farmers amounts to $R p$ 10,505,000 in one production process. The income earned by oyster mushroom farmers amounted to $R p$ 5,850,153.62 in one production process. 2). Farming oyster mushrooms, when viewed in terms of economically attempted. Judging by the value of R/C 2.2 means that every Rp 1.00 incurred costs are earned receipts of 2.2 and earn 1.2 income.
\end{abstract}

Keywords : Oyster, Mushroom Farming, Income 


\section{PENDAHULUAN}

Pengembangan usaha dibidang hortikultura merupakan suatu upaya yang dilakukan pemerintah untuk meningkatkan kontribusi sektor pertanian. Hal ini dipertimbangkan karena hortikultura merupakan sumber pertumbuhan ekonomi yang masih potensial dan belum sepenuhnya dimanfaatkan. Pengembangan komoditas hortikultura merupakan penggerak program diversifikasi, ekstensifikasi, intensifikasi, dan rehabilitasi pertanian yang merupakan inti dari kegiatan pembangunan pertanian (Budasih, dkk, 2014).

Salah satu komoditas hortikultura dari jenis sayuran yang potensial untuk dikembangkan dan memiliki prospek potensial untuk ditingkatkan adalah jamur tiram putih. Kehadiran jamur tiram sebagai salah satu jenis sayuran yang telah cukup lama dikenal oleh masyarakat di Indonesia merupakan suatu bahan pangan yang memiliki manfaat yang sanggat baik untuk kesehatan. Pada jamur tiram terdapat kandungan protein nabati yang cukup tinggi, karbohidrat yang sebanding, dan dengan kandungan lemak yang lebih rendah dari daging namun memiliki harga yang ekonomis seperti dengan sayursayuran lain. Oleh karena itu jamur tiram merupakan pilihan tepat menjadi bahan konsumsi alternatif menu makanan.

Jamur tiram atau dalam bahasa ilmiahnya disebut Pleurotus sp, banyak diketahui kalangan masyarakat. Jamur tiram mengandung zat gizi yang cukup tinggi, termasuk proteinnya disertai kadar asam amino. Adapun cara budidaya maupun pengolahan hasilnya tergolong sangat mudah, dan sangat pasarnya luas. Keunggulan jamur tiram itu sendiri adalah budidaya jamur tiram dapat dilaksanakan sepanjang tahun, menjadikan produksi jamur tiram yang melimpah. Walau pun area yang di gunakan sempit, jamur tiram masih bisa di budidayakan. Kesulitan dalam budidaya jamur tiram relatif rendah juga memiliki waktu produksi hingga panen yang tergolong cepat dibandingkan dengan jenis jamur lainnya (Nugraha, 2006).

Menurut Soenanto (2000), jamur tiram dinilai memiliki beberapa keunggulan dibandingkan jamur lainnya. Banyak kelebihan dari jamur tiram yaitu : (a) budidaya jamur tiram bisa terus berjalan sepanjang tahun, dengan demikian produksi jamur tiram yang stabil, (b) budidaya jamur tiram bisa dilaksanakan meskipun lahan yang tegolong sempit, sehingga menjadi sebuah alternatif yang baik untuk memanfaatkan lahan yang ada 
di rumah, (c) budidaya jamur tiram menggunakan bahan baku serbuk kayu yang mudah diperoleh, (d) tingkat kesulitan budidaya yang relatif sangat mudah dibandingkan dengan jenis jamur lainnya, (e) jamur tiram memiliki waktu produksi hingga masa panen yang sangat cepat diantara jamur lain, dan (f) jamur tiram memiliki tingkat harga jual yang relatif stabil dibandingkan jamur-jamur lain.

Berdasarkan pemaparan oleh beberapa ahli, jamur tiram adalah jenis sayuran yang memiliki potensi sangat mengunguntungkan karena tingginya permintaan konsumen dan masyarakat menyadari akan manfaat gizi pada kandung dalam jamur tiram mendorong peningkatan permintaan pasar terhadap komoditi sayuran ini, maraknya olahan kuliner jamur tiram juga menjadi inovasi baru bagi pengembang usaha kuliner di beberapa Kota besar untuk memanfaatkan jamur tiram menjadi hidangan yang anyak di gemari masyarakat banyak.

Produksi jamur tiram putih sangat dipengaruhi oleh teknik budidaya untuk mendapatkan hasil produk yang berkualitas baik. Dalam kegiatan budidaya jamur tiram putih, pendapatan petani dapat dipengaruhi oleh besarnya skala usaha, ketersediaan modal, harga jual produk, ketersediaan tenaga kerja keluarga dan tingkat pengetahuan dan pengalaman petani. Namun kenyataan yang terjadi dilapangan bahwa petani jarang menghitung secara pasti biaya yang dikeluarkan sehinga berpengaruh terhadap besarnya penerimaan, pendapatan dan kelayakan usahtani jamur tiram putih

Berdasarkan pemaparan dari latar belakang, maka tujuan penelitian ini adalah untuk mengetahui :

1). Biaya, penerimaan dan pendapatan usahatani jamur tiram putih di Desa Singajaya Kecamatan Cibalong. 2). Kelayakan usahtani di Desa Singajaya Kecamatan Cibalong Kabupaten Tasikmalaya.

\section{A. TINJAUAN PUSTAKA}

\section{Deskripsi Jamur Tiram Putih}

Muchrodi (2001), menjelaskan disebut jamur tiram (Pleurotus ostreatus) dikarenakan oleh bentuk tudung membulat, dan cenderung melengkung seperti kulit kerang. Jamur tiram memiliki tampilan fisik yaitu tudungnya yang menyerupai cangkang tiram dengan ukuran 5-15 cm, permukaannya lengket dan agak berminyak ketika lembab, bagian tepinya tidak rata, posisi tangkai lateral agak disamping tudung dan daging berwarna putih. 


\section{Pemilihan Bibit Jamur Tiram Putih}

Budidaya jamur sangat dipengaruhi oleh beberapa faktor yang harus diperhatikan secara detail, diantaranya adalah benih jamur (Miselium). Meskipun semua indikator pada budidaya jamur telah diterapkan tapi jika bibit miselium jamur yang digunakan kualitasnya buruk maka produksi jamur yang di inginkan akan kurang maksimal atau gagal panen (Gunawan, 2001)

Bibit unggul adalah bibit yang bersumber dari turunan pertama (F1) karena dengan menggunakan turunan F2, F3 akan menyebabkan pertumbuhan miselium berkurang produktifitasnya. Ada beberapa kriteria bibit yang baik adalah, bibit berasal dari varietas unggul dan bibit tidak terlalu tua atau sudah terlalu lamadisimpan bibit tidak terkontaminasi.

\section{Konsep Usahatani}

Ilmu Usahatani yaitu ilmu yang mendalami bagaimana cara-cara petani memperoleh dan mengkombinasikan sumber daya (lahan, tenaga kerja, modal, dan pengelolaan) yang terbatas untuk mencapai tujuannya. Menurut penguraian tersebut dapat diketahui bahwa usahatani merupakan suatu kegiatan yang di lakukan oleh petani mulai dari penentuan sumber daya yang akan digunakan serta bagimana cara mengkombinasikanya. Kondisi tersebut adalah untuk mencapai tujuannya yaitu memperoleh keuntungan (laba) yang maksimal mungkin (Soekartawi, 2011).

\section{Analisis Biaya Usahatani}

Supardi (2000) menyebutkan bahwa biaya merupakan sejumlah nominal yang dikeluarkan oleh produsen atau pengusaha supaya bisa membiayai kegiatan produksi. Biaya diartikan juga menjadi dua diantaranya biaya tetap (fixed ccost) dan biaya variabel (variabel cost) Arti biaya dalam perusahaan dibedakan menjadi dua yaitu biaya tetap dan biaya variabel yang dijelaskan sebagaiberikut:

\section{a. Biaya Tetap}

Biaya tetap yaitu biaya yang digunakan untuk dibayarkan atau dikeluarkan oleh pengusaha atau produsen dan besarnya tidak terpatok dengan tingkat output, yang ter masuk biaya tetap adalah sewa lahan atau sewa lahan, biaya penyusutan dan gaji pegawai atau karyawan.

\section{b. Biaya Variabel}

Biaya variabel adalah suatu biaya yang dikeluarkan oleh pengusaha sebagai dampak penggunaan faktor produksi yang bersifat variabel, sehingga biaya ini besarnya berubah-ubah dengan berubahnya jumlah produksi yang ingin dihasilkan 
dalam renggang waktu pendek, yang bermaksud biaya variabel merupakan biaya tenaga kerja dan biaya bahan baku.

Biaya produksi adalah sebagai pengeluaran untuk mendapatkan bahanbahan mentah yang digunakan untuk membuat barang-barang yang akan diproduksi dan faktor-faktor produksi (Agus, 2012). Biaya tetap merupakan total biaya yang dikeluarkan untuk mendapatkan faktor produksi yang tetap jumlahnya. Biaya variabel merupakan biaya yang jumlahnya berdasar dengan besarnya jumlah produksi yang ingin diperoleh.

Biaya total adalah keseluruhan biaya produksi yaitu jumlah dari biaya tetap dan biaya variabel. Total biaya bisa dirumuskan sebagai berikut :

$\mathrm{TC}=\mathrm{TFC}+\mathrm{TVC}$

Dimana : $\quad \mathrm{TC}=$ Total Biaya

$$
\begin{aligned}
& \mathrm{TFC}=\text { Biaya Tetap } \\
& \mathrm{TVC}=\text { Biaya Variabel }
\end{aligned}
$$

\section{Konsep Penerimaan}

Pendapatan kotor atau penerimaan usahatani diartikan juga seperti nilai produk keseluruhan usahatani dalam rentang waktu tertentu, baik yang dijual maupun tidak. Pengeluaran total usahatani diartikan sebagai jumlah semua masukan yang habis digunakan atau dikeluarkan di dalam produksi, tetapi tidak termasuk tenaga kerja dari keluarga petani. Pengeluaran usahatani mencakup biaya tunai dan non tunai. Jadi nilai barang dan jasa untuk keperluan usahatani yang dibayar dengan benda atau berdasarkan dengan kredit harus dimasukkan sebagai pengeluaran. Selisih antara pengeluaran total usahatani disebut pendapatan bersih dan pendapatan kotor usahatani.

\section{Konsep Pendapatan}

Pendapatan yaitu hasil materi lainnya yang diperoleh dari pemakaian kekayaan yang bebas atau berupa uang. Pendapatan umumnya adalah penerimaan - penerimaan individu atau perusahaan. Ada dua jenis pendapatan, yaitu:

a. Pendapatan kotor (gross income) merupakan penerimaan individu atau badan usaha selama waktu tertentu sebelum dikurangi dengan pengeluaranpengeluaran.

b. Pendapatan bersih (net income) merupan penghasilan sisa dan laba sesudah diambil semua biaya, pengeluaran dan penyisihan untuk penyusutan serta kerugian kerugian yang bisa muncul.

\section{Analisis Keelayakan Usahtani}

Salah satu penanda untuk mengetahui kelayakan pada suatu usaha adalah dengan menghitung Revenue Cost Ratio atau R/C Ratio. Revenue Cost Ratio atau R/C Ratio 
adalah suatu analisis yang digunakan untuk mengetahui keuntungan yang relatif pada usahatani. R/C Ratio dapat dicari dengan menggunakan perbandingan antara penerimaan Menurut Pebriantari, (2016). Kriteria kelayakan usaha pada analisis R/C Ratio yaitu:

a. Apabila hasil perhitungan R/C Ratio > 1 maka penerimaan yang diterima lebih besar dibandingkan biaya yang dikeluarkan, artinya usaha tersebut layak untuk terus dijalankan.

b. Apabila hasil perhitungan R/C Ratio < 1 maka penerimaan yang diterima lebih kecil dibandingkan biaya yang dikeluarkan, artinya usaha tersebut tidak layak untuk terus dijalankan.

c. Apabila kegiatan usaha menghasilkan $\mathrm{R} / \mathrm{C}$ Ratio = 1 maka usaha tersebut dalam keuntungan normal

\section{B. METODE PENELITIAN}

\section{Metode Pengumpulan Data}

Data yang digunakan pada penelitian ini yaitu data primer dan sekunder. Data primer didapatkan dengan pengamatan langsung (observasi), wawancara dan diskusi yang dilakukan dengan pihak internal dan eksternal petani budidaya jamur tiram. Selain itu juga, data primer berasal dari hasil pengisian kuesioner yang dilakukan oleh pihak internal dan eksternal tersebut, sedangkan data sekunder dilakukan dengan studi pustaka, yang dilakukan dengan cara membaca publikasi yang berhubungan dengan penelitian

\section{Metode Pengambilan Sampel}

Sampel yang ditarik pada penelitian ini yaitu menggunakan purposive sampling (sampel yang sengaja dipilih atau tidak acak). Teknik pengambilan sampel untuk petani jamur tiram putih ini adalah petani jamur tiram putih yaitu bapak Dedi yang menjadi satu satunya petani jamur tiram putih di Desa Singajaya Kecamatan Cibalong Kabupaten Tsikmalaya. Menurut Nasehudin dan Gozali (2012), purposive sampling merupakan salah satu teknik sampling non random dimana peneliti menentukan ciri - ciri khusus yang sesuai dengan tujuan peneliti.

\section{Rancangan Analisis Data}

Data yang diperoleh dianalisis dengan menggunakan analisis usahatani. Dalam menganalisis usahatani jamur tiram putih di Desa Singajaya Kecamtan Cibalong Kabupaten Tasikmalaya mengunakan rumus menurut Suratiyah (2009) sebagai berikut:

a. Analisis Biaya bisa mengunakan rumus

$\mathrm{TC}=\mathrm{FC}+\mathrm{VC}$

Dimana :

$\mathrm{TC}=$ Total Cost (Biaya Total) 
$\mathrm{FC}=$ Fixed Cost (Biaya Tetap Total $)$

$\mathrm{VC}=$ Variable Cost (Biaya Variabel $)$

b. Analisis Penerimaan dapat mengunakan rumus berikut :

$\mathrm{TR}=\mathrm{Py} . \mathrm{Y}$

Dimana :

$\mathrm{TR}=$ Total Revenue $($ Penerimaan Total $)$

Py $=$ Harga produk

$\mathrm{Y}=$ Jumlah produksi

c. Analisis Pendapatan mengunakan rumus :

$\mathrm{Pd}=\mathrm{TR}-\mathrm{TC}$

Dimana :

$\mathrm{Pd}=$ Pendapatan

$\mathrm{TR}=$ Total Revenue (Penerimaan Total)

$\mathrm{TC}=$ Total Cost (Biaya Total)

d. Analisis kelayakan mengunakan rumus :

$$
\mathrm{R} / \mathrm{C}=\frac{\text { Penerimaan Total }}{\text { Biaya Total }}
$$

Dimana :

$R \quad=$ Besarnya penerimaan yang diperoleh
$C=$ Besarnya biaya yang dikeluarkan

Kriteria kelayak, yaitu:

1) Apabila $R / C>1$ artinya usahatani tersebut layak

2) Apabila $R / C=1$ artinya usahatani tersebut impas

3) Apabila $\mathrm{R} / \mathrm{C}<1$ artinya usahatani tersebut tidak layak.

\section{HASIL DAN PEMBAHASAN}

\section{Analisis Biaya Usahatani Jamur}

\section{Tiram}

Biaya produksi adalah penjumlahan dari baiaya yang dikeluarkan pada setiap kali produksi, yang terdiri dari biaya tetap dan biaya variabel. Biaya tetap meliputi biaya Bangunan (PBB) dan Pajak Bumi, penyusutan alat serta bunga modal tetap.Sedangkan Biaya variabel yang dikeluarkan oleh petani jamur tiram terdiri atas miselium, pupuk, pestisida, tenaga kerja, biaya sewa dan bunga modal.

Tabel 1. Rata-rata Biaya Tetap dan Biaya Variabel Usahatani Jamur tiram per Satu Kali Panen Di Desa

\begin{tabular}{|c|c|c|c|}
\hline No & Biaya Tetap & Besarnya Biaya Tetap (Rp) & $\begin{array}{c}\text { Persentase } \\
(\%)\end{array}$ \\
\hline \multicolumn{4}{|c|}{ Penyusutan Alat dan } \\
\hline 2 & Bangunan & 550.167 & 94,57 \\
\hline 3 & Bunga Modal & $12.800,63$ & 2,21 \\
\hline \multicolumn{2}{|r|}{ JUMLAH } & $\mathbf{5 8 1 . 7 1 7 , 6 3}$ & $\mathbf{1 0 0 , 0 0}$ \\
\hline No & Biaya Variabel & Besarnya Biaya (Rp) & Persentase $(\%)$ \\
\hline 1 & Sarana Produksi & 983.500 & 24,15 \\
\hline 2 & Tenaga Kerja & 3.000 .000 & 73,65 \\
\hline 3 & Biaya Bunga Variabel & $89.628,75$ & 2,21 \\
\hline \multicolumn{2}{|r|}{ JUMLAH } & 4.073.128,75 & 100,00 \\
\hline
\end{tabular}
Singajaya 
Tabel tersebut menunjukkan bahwa biaya tetap total usahatani jamur tiram dalam satu kali proses produksi adalah $\mathrm{Rp}$ $581.717,63$. Biaya tetap yang paling besar adalah penyusutan alat dan bangunan yaitu Rp 550.167 atau 94,57 persen dari biaya total yang dikeluarkan petani. Sementara penggunaan biaya tetap lainnya yaitu pajak bumi dan bangunan Rp 18.750 (3,22\%) dan bunga atas modal tetap yang dikeluarkan $\operatorname{Rp} 12.800,63$ (2,2 \%).
Sedangkan jumlah biaya variabel total usahatani jamur tiram persatu kali panen adalah Rp 4.073.128,75 Biaya variabel yang paling besar adalah biaya tenaga kerja yaitu Rp $3.000 .000(73,65 \%)$ dari biaya total yang dikeluarkan petani.

Penggunaan biaya sarana produksi $\mathrm{Rp}$ $983.500(24,15 \%)$ dan bunga modal variabel yang dikeluarkan $\mathrm{Rp} 89.628,75$ $(2,21 \%)$ (Tabel 2).

Tabel 2. Biaya Total Usahatani Jamur Tiram Dalam Satu Kali Panen di Desa Singajaya

\begin{tabular}{cccc}
\hline No & Biaya & Jumlah (Rp) & Persentase (\%) \\
\hline 1 & Biaya Tetap & $\mathbf{5 8 1 . 7 1 7 , 6 3}$ & 12,50 \\
2 & Biaya Variabel & $\mathbf{4 . 0 7 3 . 1 2 8 , 7 5}$ & 87,50 \\
\hline & BIAYA TOTAL & $\mathbf{4 . 6 5 4 . 8 4 6 , 3 8}$ & $\mathbf{1 0 0 , 0 0}$ \\
\hline
\end{tabular}

Tabel 2 menunjukkan bahwa biaya tetap persatu kali proses panen yang dikeluarkan petani adalah $\mathrm{Rp} 581.717,63$ atau 12,50 persen dan biaya variabel yaitu $R p$ 4.073.128,75 atau 87,50 persen, sehingga biaya total $\mathrm{Rp} 4.654 .846,38$.

\section{Analisis Penerimaan dan pendapatan}

Dalam menentukkan berhasil atau tidaknya usaha dapat diukur dari besar kecilnya penerimaan dan pendapatan yang diperoleh. Besarnya penerimaan itu sendiri dipengaruhi oleh harga jual dengan jumlah produksi yang dihasilkan. Penerimaan yang diperoleh petani jamur tiram adalah jumlah panen yang dihasilkan dikalikan dengan harga yang berlaku pada saat. Biaya produksi yang dikeluarkan tiap per kali panen adalah Rp 983.500, dengan penerimaan $\mathrm{Rp}$ 10.505.000 dengan demikian rata-rata petani memperoleh pendapatan sebesar $\operatorname{Rp} 5.850 .153,62$ untuk lebih jelasnya biaya produksi, penerimaan dan pendapatan usahatani jamur tiram di Desa Singajaya 
Tabel 3. Biaya Rata-Rata Total, Penerimaan dan Pendapatan Usahatani Jamur tiram dalam Satu Kali Panen di Desa Singajaya

\begin{tabular}{cccc}
\hline No & Uraian & & Jumlah (Rp) \\
\hline 1 & Penerimaan & $\mathbf{1 0 . 5 0 5 . 0 0 0}$ \\
2 & Biaya Total & $4.654 .846,38$ \\
3 & Pendapatan & $\mathbf{5 . 8 5 0 . 1 5 3 , 6 2}$ \\
\hline
\end{tabular}

\section{Analisis Kelayakan Usahatani Jamur}

\section{Tiram Putih.}

$\mathrm{R} / \mathrm{C}$ adalah perbandingan antarà penerimaan total dengan biaya produksi total. Rata-rata R/C usahatani jamur tiram di Desa Singajaya dapat diketahui dengan rumus sebagai berikut :

$$
\begin{aligned}
R / C & =\frac{\text { rata }- \text { rata penerimaan total }}{\text { rata }- \text { rata biaya total }} \\
& =\frac{10.505 .000}{4.654 .846,38} \\
& =2,2
\end{aligned}
$$

Dari hasil perhitungan diketahui bahwa usahatani jamur tiram yang ada di Desa Singajaya memiliki nilai rata-rata R/C 2,2 hal ini menunjukkan bahwa dari setiap

satu rupiah biaya yang dikeluarkan, petani akan memperoleh penerimaan $\mathrm{Rp}$ 10.505.000 dan pendapatan atau keuntungan sebesar Rp 1,2, sehingga dapat dikatakan bahwa usahatani jamur tiram yang dijalankan petani adalah menguntungkan karena R/C lebih dari 1

\section{KESIMPULAN DAN SARAN}

\section{Kesimpulan}

Dari hasil penelitian dan pembahasan maka dapat disimpulkan sebagai berikut :

1. Biaya produksi yang dikeluarkan oleh petani jamur tiram yang berada di Desa Singajaya Kecamatan Cibalong Kabupaten Tasikmalaya adalah sebesar $\mathrm{Rp}$ 4.654.846,38, penerimaan rata-rata yang sebesar Rp 10.505.000, dan Pendapatan Rp 5.850.153,62 dalam satu kali proses produksi.

2. Usahtani jamur tiram layak diusahkan dilihat dari nilai $\mathrm{R} / \mathrm{C}$ sebesar 2,2 artinya setiap $\mathrm{Rp} 1,00$ biaya yang dikeluarkan diperoleh penerimaan sebesar 2,2 dan memperoleh pendapatan $\operatorname{Rp} 2,2$.

\section{Saran}

Dari hasil penelitian dan pembahasan, disarankan bahwa untuk meningkatkan pendapatan para petani harus menambahkan jumlah produksi, tetapi tidak lepas dari kepandaian petani jamur tiram untuk mencari pasar yang lebih banyak. 
Petani disarankan berperan aktif untuk mengikuti program peningkatan usaha rakyat, seperti pelatihan, seminar, dan lainlain yang diselenggarakan pemerintah atau lembaga terkait. Karena dengan berperan aktif petani jamur tiram akan menambah pengetahuan.

\section{DAFTAR PUSTAKA}

Agus. 2012. Manajemen Produksi Perencanaan Sistem Produksi. Yogyakarta:BPFE.

Budasih, N.L. dan Sri Astiti. 2014. Strategi Pemasaran Produk Olahan Jamur Tiram pada Kelompok Wanita Tani (KWT) Spora Bali. Jurnal Manajemen Agribisnis Volume 2 Nomor 2.Fakultas Pertanian Universitas Udayana.

Permana, G. Rochdiani, D. Yusuf, M, N. 2019. Analisis Kelayakan Usahatani Jamur Tiram di Desa Rajadesa Kecamatan Rajadesa Kabupaten Ciamis, Jawa Barat skripsi.Vol 6 Nomor 3. Ciamis :
Fakultas Pertanian, Universitas Galuh Ciamis.

Gunawan, A. W. 2001. Usaha Pembibitan Jamur Tiram Putih. Penebar Swadaya.Jakarta.

Nasehudin, dan Gozali. 2012. Metode Penelitian Kuantitatif. Bandung: CV Pustaka Setia.

Nugraha, S., dkk. 2006. Potensi dan Tingkat Kerusakan Sumberdaya Lahan di Panjaitan, F. E. D., S. N. Lubis, dan H. Hashim. 2014. Analisis efisiensi produksi dan pendapatan usahatani jagung (Stusdi Kasus: Desa Kuala, Kecamatan Tigabinaga, Kabupaten Karo). Journal On Social Economic Of Agriculture and Agribusiness. 3 (3) : 1-14.

Soekartawi. 2011. Ilmu Usaha Tani. Universitas Indonesia : Jakarta.

Soenanto, H. 2000. Jamur Tiram Budidaya dan Peluang Usaha. Aneka Ilmu. Semarang.

Supardi.I. 2000. Pembangunan Yang Memanfaatkan Sumber Daya. PT. Rineka Cipta, Jakarta.

Suratiyah. 2009. Ilmu usahatani. Penebar Swadaya. Jakarta. 